\title{
Effect of chronic oral administration of a low dose of captopril on sodium appetite of hypothyroid rats. Influence of aldosterone treatment
}

\section{R.R. Ventural, \\ E.L. Olivares ${ }^{1}$, \\ D.B. Passos Junior ${ }^{1}$, M.J. Ramalho², \\ J. Antunes-Rodrigues ${ }^{3}$ and L.C. Reis ${ }^{1}$}

\author{
1Departamento de Ciências Fisiológicas, Instituto de Biologia, \\ Universidade Federal Rural do Rio de Janeiro, Seropédica, RJ, Brasil \\ ${ }^{2}$ Departamento de Fisiologia, Instituto de Ciências da Saúde, \\ Universidade Federal da Bahia, Salvador, BA, Brasil \\ ${ }^{3}$ Departamento de Fisiologia, Faculdade de Medicina de Ribeirão Preto, \\ Universidade de São Paulo, Ribeirão Preto, SP, Brasil
}

\section{Correspondence \\ L.C. Reis \\ Departamento de Ciências \\ Fisiológicas, IB, UFRRJ \\ 23890-000 Seropédica, RJ \\ Brasil \\ Fax: +55-21-682-1763 \\ E-mail: Icreis@ ufrrj.br}

Presented at the XV Annual Meeting of the Federação de Sociedades de Biologia Experimental, Caxambu, MG, Brazil, August 23-26, 2000

Research supported by PRO NEX/MCT. Publication supported by FAPESP

Received April 12, 2000 Accepted December 4, 2000

\section{Abstract}

Rats rendered hypothyroid by treatment with methimazole develop an exaggerated sodium appetite. We investigated here the capacity of hypothyroid rats ( $\mathrm{N}=12$ for each group) to respond to a low dose of captopril added to the ration, a paradigm which induces an increase in angiotensin II synthesis in cerebral areas that regulate sodium appetite by increasing the availability of circulating angiotensin I. In addition, we determined the influence of aldosterone in hypothyroid rats during the expression of spontaneous sodium appetite and after captopril treatment. Captopril significantly increased $(\mathrm{P}<0.05)$ the daily intake of $1.8 \% \mathrm{NaCl}$ (in $\mathrm{ml} / 100 \mathrm{~g}$ body weight) in hypothyroid rats after 36 days of methimazole administration (day 36: $9.2 \pm 0.7 v s$ day 32: 2.8 $\pm 0.6 \mathrm{ml}$, on the 4 th day after captopril treatment). After the discontinuation of captopril treatment, daily $1.8 \% \mathrm{NaCl}$ intake reached values ranging from $10.0 \pm 0.9$ to $13.9 \pm 1.0 \mathrm{ml}, 48$ to 60 days after treatment with methimazole. Aldosterone treatment significantly reduced $(\mathrm{P}<0.05)$ saline intake before $(7.3 \pm 1.6 v s$ day $0,14.4 \pm 1.3 \mathrm{ml})$ and after captopril treatment. Our results demonstrate that, although hypothyroid rats develop a deficiency in the production of all components of the renin-angiotensin-aldosterone system, their capacity to synthesize angiotensin II at the cerebral level is preserved. The partial reversal of daily $1.8 \% \mathrm{NaCl}$ intake during aldosterone treatment suggests that sodium retention reduces both spontaneous and captopril-induced salt appetite.

Previous studies have shown a reduction in $\mathrm{NaCl}$ aversion in hypothyroid rats with urinary sodium loss and an increase in sodium appetite in different experimental models (1-4). However, controversies still exist regarding the physiological mechanism re-

\section{Key words}

- Sodium appetite

- Hypothyroidism

- Captopril

- Aldosterone

- Rats sponsible for sodium appetite, since genetic expression, synthesis and release of the components of the renin-angiotensin-aldosterone system are reduced in hypothyroidism (3,59). Moreover, angiotensin II receptor density is altered in hypothyroidism. An increase in 
the expression of AT2 receptors was observed in heart, liver, kidney and adrenals, whereas AT1 receptor density was unaltered (7). In this study the influence of hypothyroidism on the density of cerebral AT1 receptors was not investigated (7). Various studies have suggested the involvement of AT1 receptors in the expression of sodium appetite behavior using central administration of antagonists specific for these receptors (10-12). These alterations were revealed concomitantly with the observation of low genetic expression and reduced basal and stimulated release of atrial natriuretic peptide in hypothyroidism $(9,13,14)$ together with the decreased capacity of proximal tubular sodium reabsorption (15). Literature data have led to the conclusion that the sodium appetite of hypothyroid rats is unique because it occurs in the presence of reduced plasma levels of both aldosterone and angiotensin II (3,5-9).

The study of sodium appetite behavior is clearly relevant in view of the water-electrolyte and cardiovascular changes observed in hypothyroidism. There are no reports on the capacity of hypothyroid rats to respond to a natriorexigenic stimulus of low captopril doses.

In the present study we determined the capacity of hypothyroid rats to respond to a low dose of captopril added to the food. This experimental paradigm elevates cerebral angiotensin I availability and induces an increase in sodium intake following neuronal production of angiotensin II (12,16-18), without alterations in water intake. Administration of captopril to rats in the diet $(0.7 \mathrm{mg} / \mathrm{g}$ of food) or added to the drinking water (about $0.7-1 \mathrm{mg} / \mathrm{ml}$ ) induced an increase in the ingestion of hypertonic saline $(16,17)$. Low doses of captopril $(12 \mu \mathrm{g} / \mathrm{h})$ infused intracerebroventricularly inhibited the sodium appetite which follows oral captopril. Continuous intravenous infusion of high doses of captopril (25-500 mg/day) does not induce sodium appetite. When the dose was re- duced to a low value ( $5 \mathrm{mg} /$ day), $\mathrm{NaCl}$ intake increased. These data suggested to the authors that low captopril concentrations do not cross the blood-brain barrier in sufficient amounts to block the angiotensin-converting enzyme, resulting in an increase in the circulating levels of angiotensin I that stimulate sodium appetite upon conversion to angiotensin II in the brain $(12,17)$. The conversion of angiotensin I to angiotensin II, required for the manifestation of sodium appetite after treatment with low captopril doses, probably occurs in the subfornical organ and organum vasculosum lamina terminalis, structures in which angiotensin-converting enzyme has been identified $(19,20)$.

An additional objective was to determine the influence of aldosterone administration on sodium appetite of hypothyroid rats before and during treatment with captopril. In the experimental hypothyroidism induced in rats, hypoaldosteronism occurs, due to deficiency of all the components of the reninangiotensin system, and this causes urinary sodium loss and compensatory expression of sodium appetite $(1,7)$. For this reason, hypothyroid rats develop an inability to maintain their sodium balance (1-3). Therefore, hormonal replacement by daily administration of aldosterone would restore the capacity to retain sodium in hypothyroid rats $(1,3)$.

Male Wistar rats weighing 235-255 g maintained in the animal house under controlled light and temperature conditions (lights on from 6:00 to 19:00 h) were used. Hypothyroidism was induced by methimazole $(0.05 \%$ in drinking water; Eli Lilly do Brasil Ltda., São Paulo, SP, Brazil). To test the efficiency of antithyroid treatment, plasma T4 and TSH levels were determined by radioimmunoassay (kits from Abbott do Brasil, São Paulo, SP, Brazil). Thirty and 60 days after treatment with methimazole, plasma TSH levels were higher than $25.0 \mathrm{ng} /$ $\mathrm{ml}$ (euthyroid rats $<1.5 \mathrm{ng} / \mathrm{ml}$ ) and T4 levels were lower than $1.2 \mu \mathrm{g} / \mathrm{dl}$ (euthyroid rats $>4.0 \mu \mathrm{g} / \mathrm{dl}$ ). Thirty days after treatment with 
methimazole, body weight gain was always lower than $10 \%$, whereas in euthyroid rats an increase higher than $30 \%$ was always observed. Euthyroid and hypothyroid rats $(\mathrm{N}=12$ for each group) received $1.8 \% \mathrm{NaCl}$ and water and ration ad libitum throughout the experiment. After 32 days of methimazole treatment, captopril, an angiotensin-converting enzyme inhibitor (Bristol-Myers Squibb, São Paulo, SP, Brazil), was added to the food (1 mg/g ration). One of the hypothyroid groups received the mineralocorticoid d-aldosterone (Sigma Chemical Co., St. Louis, MO, USA) for 7 days (100 $\mu \mathrm{g} / \mathrm{kg}, s c$, in corn oil solution) before and during captopril treatment. Under all experimental conditions, water and $1.8 \% \mathrm{NaCl}$ were offered simultaneously to the animals, which were maintained in metabolic cages fitted with graduated water bottles.

Data are reported as mean \pm SEM and were analyzed statistically by analysis of variance for repeated measures followed by the Student-Newman-Keuls test. Differences between means were considered to be significant when $\mathrm{P}<0.05$.

Euthyroid rats treated with captopril showed an increase in $1.8 \% \mathrm{NaCl}$ intake which reached a peak of $11.9 \pm 1.1 \mathrm{ml}$ on the 4th day post-treatment (day 0: $0.5 \pm 0.2 \mathrm{ml}$ ) without significant alterations in water intake (data not shown).

Figure 1 shows that captopril treatment significantly increased daily intake of $1.8 \%$ $\mathrm{NaCl}$ (reported as $\mathrm{ml} / 100 \mathrm{~g}$ body weight) in hypothyroid rats at 36 days of methimazole administration (day 36: $9.2 \pm 0.7 v s$ day 32: $2.8 \pm 0.6 \mathrm{ml}$, on the 4 th day after captopril treatment). After the discontinuation of captopril treatment, daily $1.8 \% \mathrm{NaCl}$ intake decreased gradually until day 42 and then started to increase, reaching mean values of $10.0 \pm$ 0.9 to $13.9 \pm 1.0 \mathrm{ml}$ between 48 and 60 days post-treatment with methimazole. Captopril treatment increased water intake in a more discrete but significant manner (day 36: 9.3 $\pm 0.6 v s$ day $32: 6.9 \pm 0.6 \mathrm{ml}$ ). Hypothyroid rats not treated with captopril also reached levels of $1.8 \% \mathrm{NaCl}$ intake above $10.0 \mathrm{ml}$ but only from day 56 on and with a less pronounced ascending curve than that observed for hypothyroid rats treated with captopril. Sodium appetite was determined daily in both groups until the 60th day posttreatment with methimazole. In parallel, separate groups of hypothyroid rats previously treated or not with captopril were followed up for 12 months. During this period, both groups showed levels of $1.8 \% \mathrm{NaCl}$ intake ranging from 10.0 to $14.0 \mathrm{ml} / 100 \mathrm{~g}$ (data not shown).

Figure 2 shows that aldosterone administration drastically decreased the intake of $1.8 \% \mathrm{NaCl}$ before treatment $(7.3 \pm 1.6 v s$ day $0: 14.4 \pm 1.3 \mathrm{ml}$ ) and attenuated the natriorexigenic response induced by the concomitant administration of a low captopril dose. In this condition water intake was unchanged. The discontinuation of aldosterone treatment led to an elevation in salt intake, reaching values of $20.2 \pm 1.9 \mathrm{ml} 5$ days after

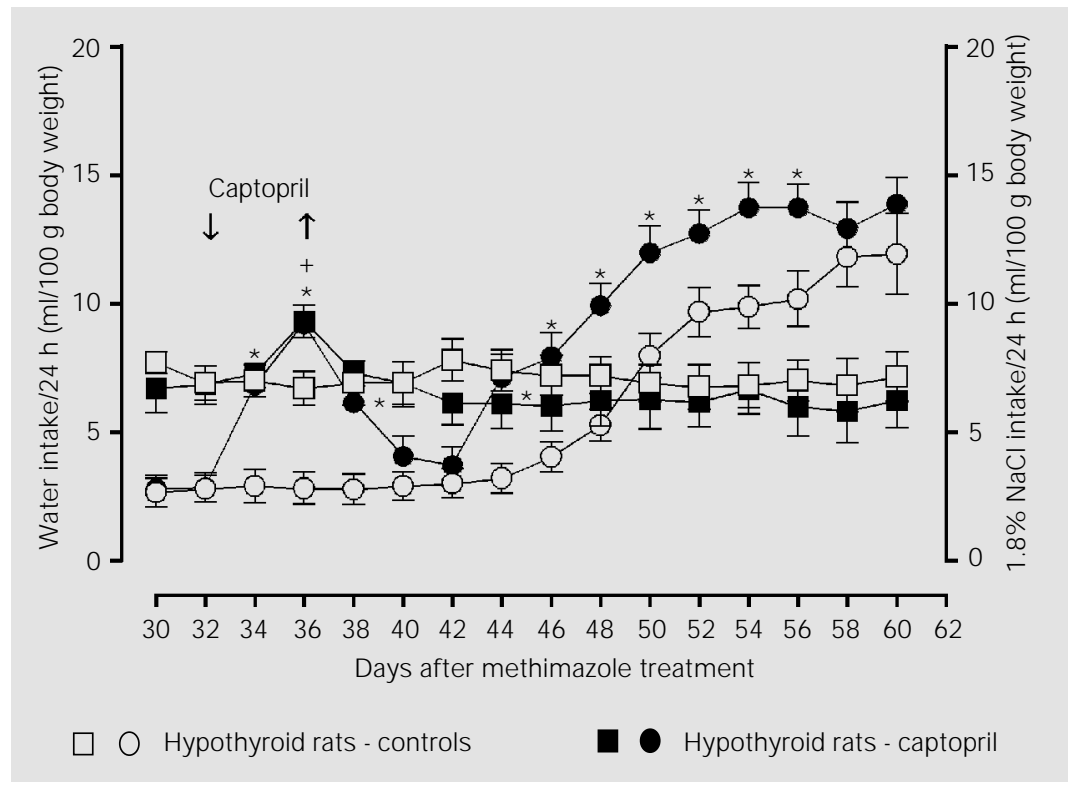

Figure 1 - Mean 24-h water (squares) and sodium (circles) intake of hypothyroid rats treated with captopril ( $1 \mathrm{mg} / \mathrm{g}$ added to the food, from day 32 to day 36$)$. Arrows represent days on which captopril was added and removed from the food. $*+\mathrm{P}<0.05$ for $1.8 \% \mathrm{NaCl}$ and water intake, respectively, compared to hypothyroid control rats (ANOVA and Student-NewmanKeuls test). 


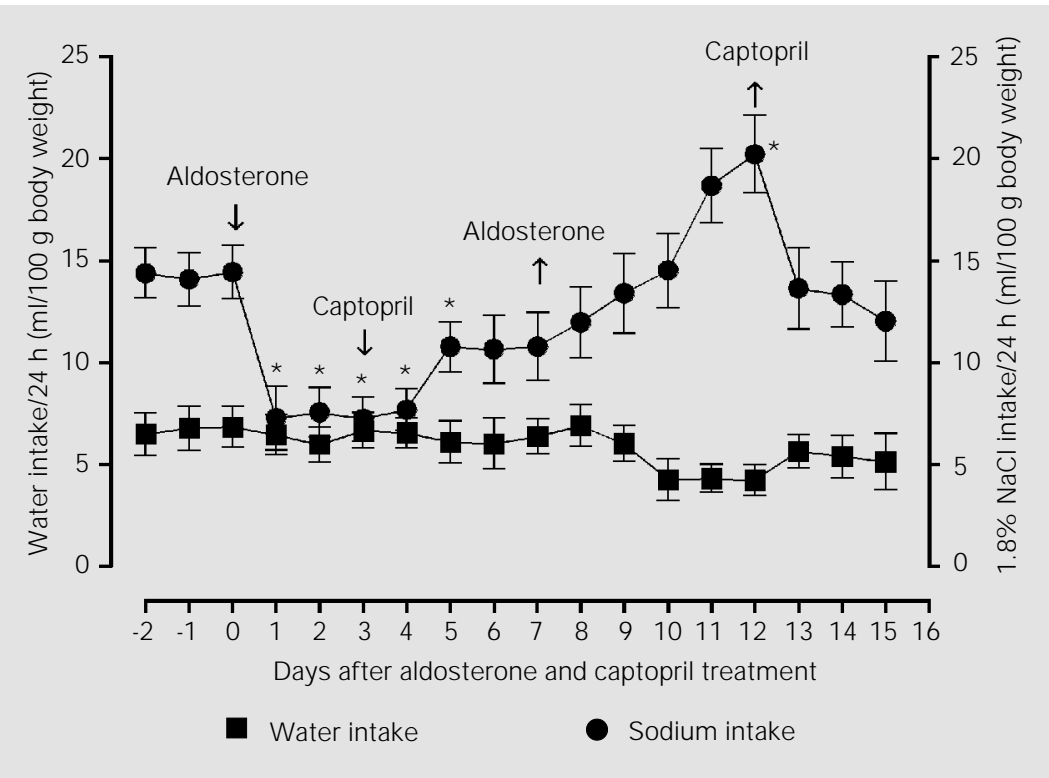

Figure 2 - Influence of aldosterone administration (100 $\mu \mathrm{g} / \mathrm{kg}$, sc, for 7 days) on water (squares) and $1.8 \% \mathrm{NaCl}$ intake (circles) of hypothyroid rats before and after captopril treatment ( $1 \mathrm{mg} / \mathrm{g}$ added to the food from day 3 to day 12 ). Arrows represent days on which aldosterone and captopril were given or interrupted. $* \mathrm{P}<0.05$ compared to day zero (ANOVA and Student-Newman-Keuls test). controversy might arise since some of these authors used isotonic saline in their studies which may lead to the interpretation that the palatable component constitutes a more predominant factor in salt intake by hypothyroid rats.

Our results demonstrate that hypothyroid rats respond to the natriorexigenic stimulus of a low captopril dose added to the ration. Since the synthesis of components of the renin-angiotensin-aldosterone system is depressed in hypothyroidism one may speculate that the low plasma angiotensin I levels produced in our experimental model represent a stimulus sufficient to induce a natriorexigenic response and a more discrete increase in water intake. These observations lead us to hypothesize that in the model of hypothyroidism used here the cerebral angiotensinergic system involved in the mediation of sodium appetite possesses a component highly sensitive to circulating angiotensin I levels. The reduction in spontaneous sodium appetite intensity and the partial reversal of the natriorexigenic response to captopril observed after aldosterone treatment may suggest that the increase in sodium concentration in the body fluids depresses the conversion of angiotensin I to angiotensin II and/or the expression of AT1 receptors and cerebral angiotensinergic activity in hypothyroidism.

The present results demonstrate that hypothyroid rats develop a more intense sodium appetite after oral captopril treatment. The expression of spontaneous sodium appetite and the natriorexigenic response induced by captopril administration were reduced in hypothyroid rats after aldosterone treatment.

\section{Acknowledgments}

We thank Mr. Ipojucan Pereira de Souza for technical assistance and animal care. 


\section{References}

1. Taylor J r RE \& Fregly MJ (1964). Renal response of propylthiouracil-treated rats to injected mineralocorticoids. Endocrinology, 75: 33-41.

2. Fregly MJ \& Taylor J r RE (1964). Effect of thyroxine on intake and loss of sodium by propylthiouracil-treated rats. Endocrinology, 75: 27-32.

3. Fregly MJ \& Rowland NE (1985). Role of renin-angiotensin-aldosterone system in $\mathrm{NaCl}$ appetite of rats. American J ournal of Physiology, 248: R1-R11.

4. Belló AA \& Covian MR (1991). Rats with spontaneous high level of $\mathrm{NaCl}$ intake have hypothyroidism. Physiology and Behavior, 50: 1071-1073.

5. Bouhnik J, Galen FX, Clauser E, Menard J \& Corvol J (1981). The renin-angiotensin system in thyroidectomized rats. Endocrinology, 108: 647-650.

6. Montiel $M$, J iménez $E$, Narvaez J A \& Morell M (1982). Renin-angiotensin-aldosterone system in hyper- and hypothyroid rats during sodium depletion. Endocrine Research Communications, 9: 249-260.

7. Marchant C, Brown L \& Sernia C (1993). Renin-angiotensin system in thyroid dysfunction in rats. J ournal of Cardiovascular Pharmacology, 22: 449-455.

8. Costerousse $\mathrm{O}$, Allegrini $\mathrm{J}$, Huang $\mathrm{H}$, BouhnikJ \& Alhenc-Gelas F (1994). Regulation of ACE gene expression and plasma levels during rat postnatal development. American J ournal of Physiology, 267:
E745-E753.

9. Yegin E, Yigitoglu R, Ari Z, Celik I, Akcay $F$ $\&$ Suzek H (1997). Serum angiotensin-converting enzyme and plasma atrial natriuretic peptide levels in hyperthyroid and hypothyroid rabbits. J apanese Heart J ournal, 38: 273-279.

10. Beresford MJ \& Fitzsimons JT (1992). Intracerebroventricular angiotensin II-induced thirst and sodium appetite in rat are blocked by the AT1 receptor antagonist, losartan (DuP 753), but not by the AT2 antagonist, CGP 42112B. Experimental Physiology, 77: 761-764.

11. Galaverna O, Polidori C, Sakai RR, Liénard F, Chow SY \& Fluharty SJ (1996). Blockade of central angiotensin II type 1 and type 2 receptors suppresses adrenalectomy-induced $\mathrm{NaCl}$ intake in rats. Regulatory Peptides, 66: 47-50.

12. Fitzsimons J T (1998). Angiotensin, thirst, and sodium appetite. Physiological Reviews, 78: 583-686.

13. Ladenson PW, Bloch KD \& Seidman J G (1988). Modulation of atrial natriuretic peptide factor by thyroid hormone: Messenger ribonucleic acid and peptide levels in hypothyroid, and hyperthyroid rat atria and ventricles. Endocrinology, 123: 652657.

14. Wong NL, Huang D, Guo NS, Wong EF \& Hu DC (1989). Effects of thyroid status on atrial natriuretic peptide release from isolated rat atria. American J ournal of Physi- ology, 256: E64-E67.

15. Zimmerman RS, Ryan J, Edwards BS, Klee G, Zimmerman D, Scott N \& Burnett J r JC (1988). Cardiorenal endocrine dynamics during volume expansion in hypothyroid dogs. American J ournal of Physiology, 255: R61-R66.

16. Fregly MJ (1980). Effect of the angiotensin converting enzyme inhibitor, captopril on $\mathrm{NaCl}$ appetite of rats. J ournal of Pharmacology and Experimental Therapeutics, 215: 407-412.

17. Elfont RM, Epstein NA \& Fitzsimons JT (1984). Involvement of the renin-angiotensin system in captopril-induced sodium appetite in the rat. J ournal of Physiology, 354: 11-27.

18. Fitzsimons J T (1986). Endogenous angiotensin and sodium appetite. In: de Caro G, Epstein NA \& Massi M (Editors), The Physiology of Thirst and Sodium Appetite. Plenum Press, New York.

19. Mendelsohn FAO, Quirion R, Saavedra J M, Aguilera G \& Catt KJ (1984). Autoradiographic localization of angiotensin II receptor in rat brain. Proceedings of the National Academy of Sciences, USA, 81: 1575-1579.

20. Rauch M \& Schmidt HA (1999). Functional evidence for subfornical organ intrinsic conversion of angiotensin I to angiotensin II. American J ournal of Physiology, 276: R1630-R1638. 